\title{
COMPARATIVE EVALUATION OF FECUNDITY AND SURVIVORSHIP OF SIX COPEPOD (COPEPODA: CYCLOPIDAE) SPECIES, IN RELATION TO SELECTION OF CANDIDATE BIOLOGICAL CONTROL AGENTS AGAINST AEDES AEGYPTI
}

\author{
TRAN VU PHONG, NOBUKO TUNO, HITOSHI KAWADA AND MASAHIRO TAKAGI
}

Department of Vector Ecology and Environment, Institute of Tropical Medicine, Nagasaki University, Nagasaki 8528523, Japan

\begin{abstract}
The fecundity and survival of 6 copepod species were assessed under laboratory conditions in order to choose the best candidates to control the aquatic stages of dengue mosquitoes in the field. Females of all the 6 species (Mesocyclops aspericornis, Mesocyclops pehpeiensis, Mesocyclops woutersi, Mesocyclops thermocyclopoides, Mesocyclops ogunnus, and Megacyclops viridis) mated more than once. Multiple mating resulted in increased egg production. The reproductive ability and longevity varied among the species, and $M$. aspericornis had the highest values. The lowest values were observed in $M$. thermocyclopoides. Multiple mating of males of $M$. aspericornis was also observed. The paternal fecundity decreased with each additional mating. There was no difference in the paternal fecundity between the males that mated at low and high female frequencies. The sperm stored in the M. aspericornis females remained viable for 30 days after storage under moist conditions at $25^{\circ} \mathrm{C}$ or $15^{\circ} \mathrm{C}$. This feature in M. aspericornis represents an additional positive factor indicating that this species is a good biological agent for controlling mosquito larvae, especially in domestic water containers that may dry intermittently.
\end{abstract}

KEY WORDS Copepods, mating, sperm, reproductive ability, vector control, dengue

\section{INTRODUCTION}

The overlap in the spatial distribution and habitats of predatory copepods, genus Mesocyclops (Sars), and their aquatic prey, larval stages of Aedes aegypti (Linnaeus), makes them efficacious in dengue vector control (Phong et al. 1996, Nam et al. 2000, Torres-Estrada et al. 2001, Kay and Nam 2005, Nam et al. 2005) or malaria control (Marten et al. 1989). Several species of cyclopoids have been used singly (Lardeux 1992, Marten et al. 1994, Torres-Estrada et al. 2001) or as mixtures of species found to preexist in water storage containers or natural pools (Marten et al. 1989, Nam et al. 2005), but up until now, the decision about the selection of appropriate candidates has been made in the absence of definitive knowledge of the reproductive potential and longevity of these species.

Reproduction in freshwater copepods is influenced by species-specific factors, including nutrition (Maier 1995, Hansen and Santer 1995, Hopp et al. 1997, Dieng et al. 2003), temperature (Wyngaard 1986, Melao et al. 2004), and mating availability (Williamson and Butler 1987, Maier 1995). Cyclopoid copepod females store the sperm in their seminal receptacles and produce multiple egg clutches from a single fertilization (Maier 1995, Hopp et al. 1997, Buskey 1998). Maier (1995) concluded that 1 mating is generally sufficient for the fertilization of multiple clutches in cyclopoid copepod females, and remating is rare and unnecessary in the cyclopoids, Cyclop vicinus (Uljanin) and Metacyclops minutus (Claus). However, it is not known whether a single mating is sufficient for Mesocyclops females to realize their maximum potential fecundity.

In this study, we report the influence of mating frequency on female fecundity in 5 species of Mesocyclops that are commonly found and are being used as biological agents for dengue vector control in Vietnam and in Megacyclops viridis (Jurine). Megacyclops viridis, also a predator of Aedes albopictus (Skuze) larvae (Dieng et al., 2003), is found in Japan but is rare in Southeast Asia. Additionally, we measured male fecundity of Mesocyclops aspericornis (Daday) for the purpose of knowing the influence of the male's mating behavior on the female's lifetime fecundity.

Resistance to desiccation and survival of copepods under moist conditions have been reported (Zhen and Jennings 1994, Maria et al. 2001). However, the reproductive ability and longevity of such copepods following subsequent inundation have not been assessed. We also assessed the reproductive ability and longevity of mated females of M. aspericornis after 30 days of storage on moist filter paper to improve the delivery system to local communities wishing to initiate programs for dengue vector control.

\section{MATERIALS AND METHODS}

\section{Copepods}

Laboratory stocks of $M$. aspericornis, Mesocyclops ogunnus (Onabamiro), Mesocyclops pehpeiensis $(\mathrm{Hu})$, Mesocyclops thermocyclopoides 
(Harada), and Mesocyclops woutersi (Van de Velde) (identified using the keys of Holynska et al. 2003) were obtained from females collected in northern Vietnam. A stock of $M$. viridis was obtained from females collected in Nagasaki, southwestern Japan. Mass cultures of the respective species were maintained in 15-liter plastic boxes $(28 \times 38 \times 14 \mathrm{~cm})$ according to the method described by Suarez et al. (1992). The copepods were fed a Paramecium-Chilomonas infusion that was cultured with wheat seeds ( 5 seeds per liter) in 10-liter plastic cans. The 7-day-old infusion was used as the copepod culture medium in all the experiments. All experiments were conducted at temperatures of $25^{\circ} \mathrm{C} \pm 1^{\circ} \mathrm{C}$ under a $14: 10$-h light:dark photoperiod in the laboratory.

\section{Observation of remating}

Ten $M$. aspericornis females that ceased producing egg clutches for 5 days were each paired with a newly matured male. The spermatophore transfer was observed at $10 \times$ magnification for each pair, and hatching of embryos into nauplii was noted.

\section{Influences of mating frequency on maternal fecundity}

The primiparous females, 30 of each species, were isolated individually into $30-\mathrm{ml}$ glass vials containing $20 \mathrm{ml}$ of the culture medium. Each female was monitored daily to count the number of egg clutches, interclutch period, reproductive period, and longevity until death. When a female did not produce egg clutches for 5 days, she was allowed to mate with a newly matured male, as mentioned above. The male was removed when the female produced a clutch. The broods of these mothers were reared separately to record the number of progeny and the developmental period from egg to adult.

As a control, we used 30 newly ovigerous $M$. aspericornis females that mated only once. Their lifetime fecundity was individually monitored until death, to compare it with that of the remated $M$. aspericornis female group.

The number of eggs in a pair of egg sacs (clutch size) was determined by counting the number of eggs in both egg sacs in 100 females of each copepod species by using a compound microscope at $20 \times$ magnification.

\section{Influence of mating frequency on paternal fecundity}

Two days after reaching the copepodite IV stage, mature males were placed with 1 (1-F group) or 10 (10-F group) virgin females for mating in a $200-\mathrm{ml}$ plastic cup containing $150 \mathrm{ml}$ of the culture solution. In each group, 10 males were observed individually twice a day, at 10:00 a.m. and 4:00 p.m. Females observed carrying egg sacs were transferred into $30-\mathrm{ml}$ vials to monitor lifetime fecundity. A virgin female was introduced into the $1-\mathrm{F}$ and $10-\mathrm{F}$ groups each time an eggbearing female was removed in order to maintain a constant male:female ratio. The males were monitored until death to determine the length of their reproductive period; longevity; and the number of inseminated females, egg clutches, and matured offspring.

\section{Fecundity after 30 days of storage}

Two hundred newly matured $M$. aspericornis females were maintained on moist filter paper in a 200-ml covered plastic cup (with a diameter of $10 \mathrm{~cm}$ and a height of $4 \mathrm{~cm}$ ) at $25^{\circ} \mathrm{C}$ or $15^{\circ} \mathrm{C}$. After 30 days, they were submerged in the culture solution in $1,000-\mathrm{ml}$ plastic cups. Twenty-four hours later, 30 egg-bearing females of each group (stored at $25^{\circ} \mathrm{C}$ or $15^{\circ} \mathrm{C}$ ) were isolated individually in $30-\mathrm{ml}$ vials containing $20 \mathrm{ml}$ of the culture solution. They were monitored daily until death to determine their lifetime fecundity, reproductive period, and longevity. Thirty newly ovigerous $M$. aspericornis females that were not subjected to the 30-day storage period were monitored in the same manner as the controls.

\section{Data analysis}

The number of hatched egg clutches in the single- and multiple-mated groups was compared using a Mann-Whitney $U$-test. We compared the total number of egg clutches, clutch size, interclutch periods, reproductive period, and longevity between 6 female species using analysis of variance (ANOVA), after testing for the normal distribution of each trait. The number of copulations, egg clutches, and offspring in $M$. aspericornis males was compared between the 1$\mathrm{F}$ and $10-\mathrm{F}$ groups, using a $t$-test with Bonferroni adjustment. These traits were also compared between the groups of females stored on wet filter paper for 30 days. The number of egg clutches and total number of offspring produced per lifetime, after we normalized using a $\log _{10}+1$ transformation, was regressed on the ordinal number of copulatory events of $M$. aspericornis males to examine the influence of multiple matings in a lifetime. All statistical analyses were performed using Systat version 7.0 (SPSS Inc., Chicago).

\section{RESULTS \\ Mating behavior}

Successful spermatophore transfer to an $M$. aspericornis gravid female, which had produced 6 egg clutches and had no egg sac 5 days before the 


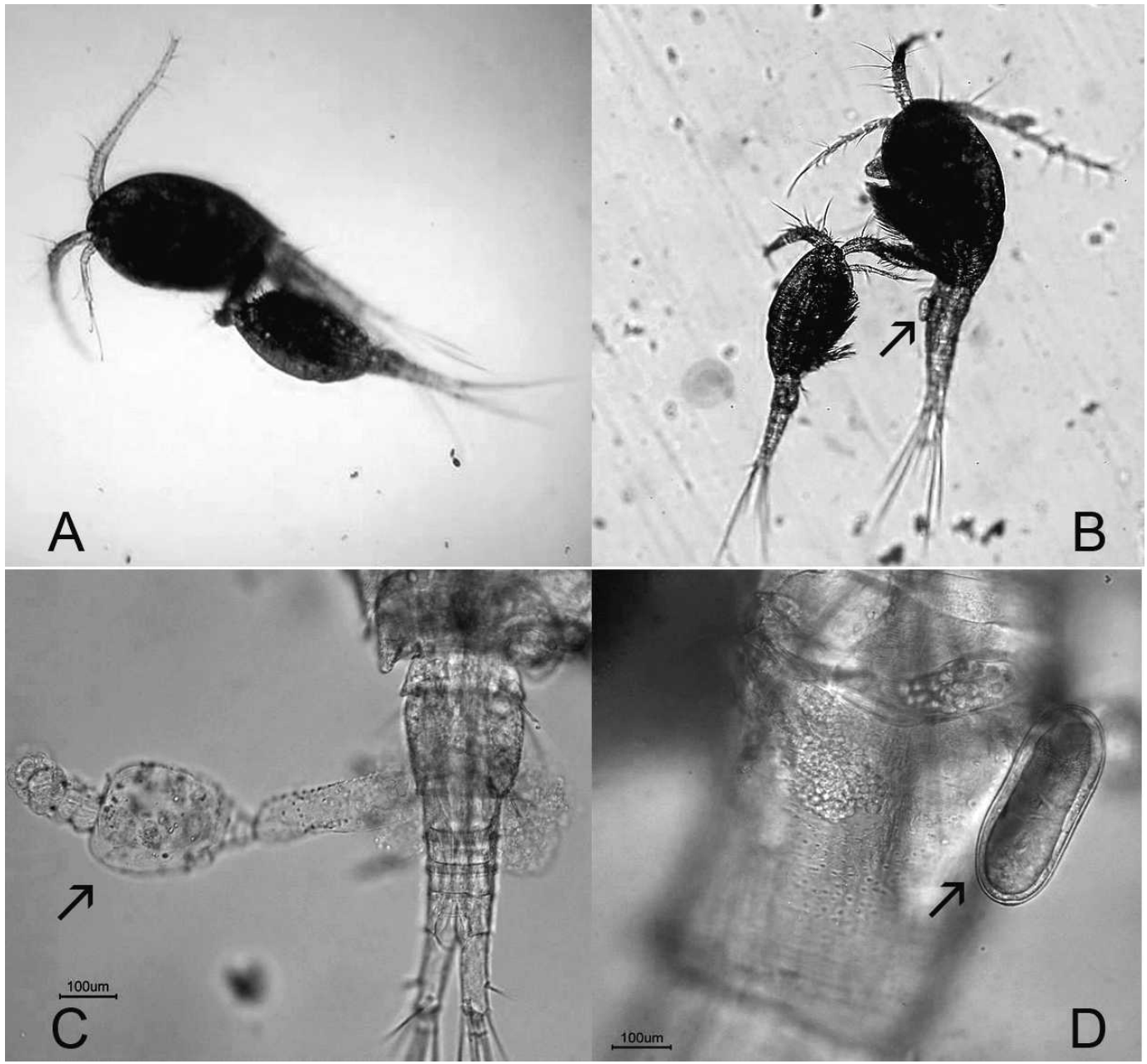

Fig. 1. Mating in M. aspericornis. (A) Ventral-to-ventral copulatory position; (B) Immediately after mating, the spermatophores are fixed at the genital segment of a virgin female (arrow); (C) Immature spermatophores of the male after the 1st mating; (D) The spermatophores of the 2nd mating are fixed at the genital segment of a gravid female (which had produced 6 egg clutches from the 1st mating).

2nd copulation, was observed. Figure 1 is presented as evidence of remating.

\section{Influences of mating frequency on maternal fecundity}

Maternal remating was observed in $73.3-100 \%$ of females of 5 Mesocyclops species tested. The proportion of remating in $M$. viridis was lower (46.7\%). A 2nd insemination was observed in $100 \%$ of $M$. aspericornis females, and a $3 \mathrm{rd}$ and 4th insemination in $37 \%$ and $11 \%$, respectively (Fig. 2A). There were significant differences in the lifetime maternal fecundity of the 5 Mesocyclops species tested $\left(\mathrm{F}_{4,148}=14.4, P<0.001\right)$. The mean number of egg clutches of $M$. aspericornis was the highest, followed by $M$. pehpeiensis, $M$. woutersi, $M$. ogunnus, and $M$. thermocyclopoides (Table 1). The clutch sizes differed among the species $\left(\mathrm{F}_{5,594}=332.5, P<\right.$ 0.001). Mesocyclops aspericornis bore the largest mean number of eggs per clutch, followed by $M$. pehpeiensis, M. thermocyclopoides, M. woutersi, $M$. ogunnus, and $M$. viridis (Table 2).

Remating increased the lifetime fecundities of all 6 species. The contribution of the 1 st mating to the lifetime fecundity (number of clutches) was $0.32,0.34,0.34,0.49,0.67$, and 0.76 , while the proportion of mature offspring produced by the 1 st mating was $0.36,0.35,0.35,0.51,0.71$, and 0.83 in $M$. aspericornis, $M$. pehpeiensis, $M$. woutersi, $M$. ogunnus, $M$. thermocyclopoides, and $M$. viridis, respectively. The lifetime fecundities and number of mature offspring resulting from the remated females of $M$. aspericornis were higher than those of the single-mated females $\left(t_{1}\right.$, ${ }_{58}=8.9$ and 9.8 , respectively, $P<0.001$ ) (Fig. 2B). 


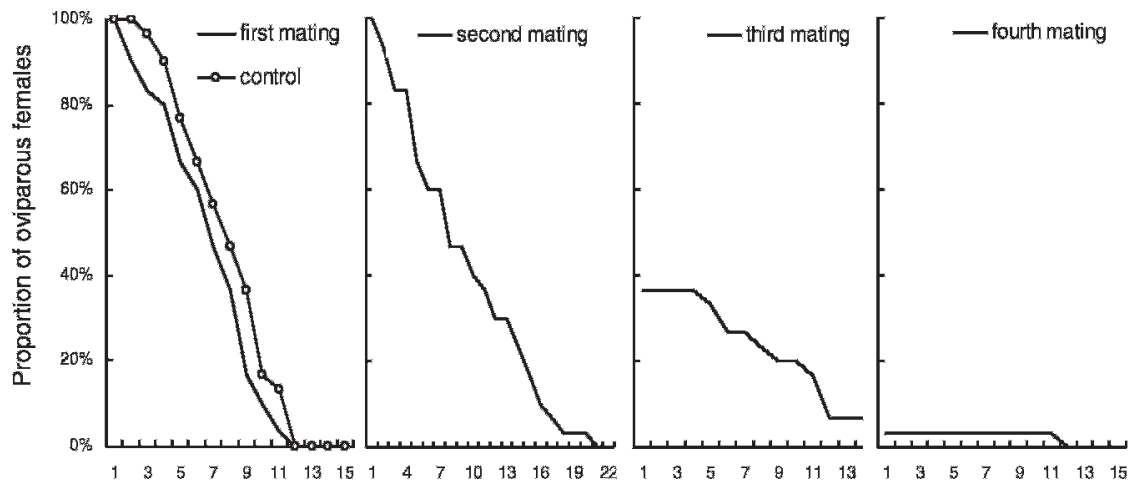

A

Sequence of oviparous fermales

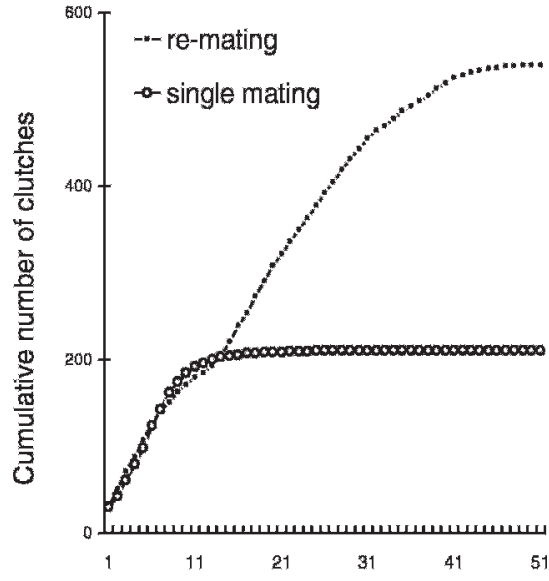

B

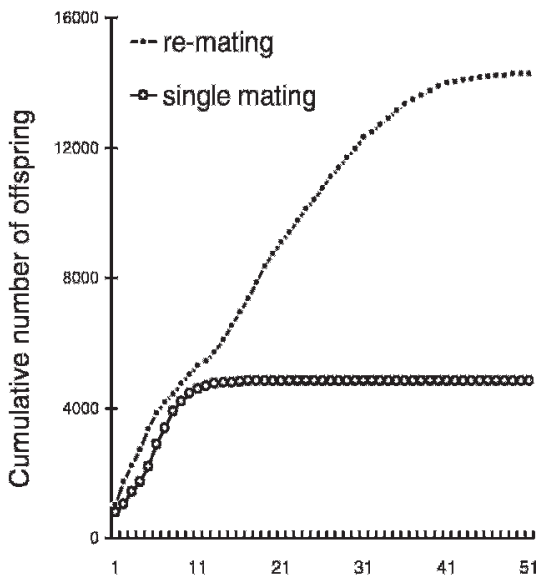

Time (days)

Fig. 2. The number of clutches produced by successive matings in M. aspericornis. (A) The proportion of females producing different number of clutches is shown for a group of 30 females after they were mated 1, 2, 3, and 4 times. The control refers to a group of 30 females that was mated only once. (B) Cumulative number of clutches and offspring of 30 females that were mated only once or multiple times. Lifetime fecundities and number of mature offspring resulting from the remated females of $M$. aspericornis were higher than those of the single-mated females $\left(t_{1,58}=8.9\right.$ and 9.8 , respectively, $\left.P<0.001\right)$.

There was no difference between the interclutch periods following the 1st mating and those of subsequent matings (1.42 and 1.39 days in average, $\left.t_{1}, 1,565=0.9, P>0.05\right)$ in 5 Mesocyclops species. However, the interclutch periods differed across the species $\left(\mathrm{F}_{1,2,121}=\right.$ $36.2, P<0.001)$. The interclutch periods of $M$. viridis (2.0 days) were longer than those of the 5 Mesocyclops species (Table 2).

Remating prolonged the maternal reproductive period of $M$. aspericornis. The duration of the reproductive period was $4.5 \times$ greater in the multiple-mated females (43 days) than in the single-mated ones ( 9 days). Moreover, remating did not reduce the longevity of $M$. aspericornis. There was no difference $\left(t_{1,58}=0.56, P>0.05\right)$ in longevity between the single-mated and the multiple-mated females. However, the individual reproductive outputs (number of egg clutches) showed variations and were positively correlated with the longevity of females

$\left(\mathrm{F}_{1,180}=65.9, P<0.001\right)$. Nevertheless, the longevity of females varied among the species. Mesocyclops aspericornis had the highest average longevity (74.5 days), followed by $M$. viridis (65.0), M. woutersi (56.5), M. pehpeiensis (50.9), $M$. ogunnus (43.1), and $M$. thermocyclopoides (31.2) (Table 2).

\section{Influence of mating frequency on paternal fecundity}

All $M$. aspericornis males remated with a high frequency in both the 1-F group (mean number is $8.5 \pm 1.1$ matings) and the $10-\mathrm{F}$ group (mean 


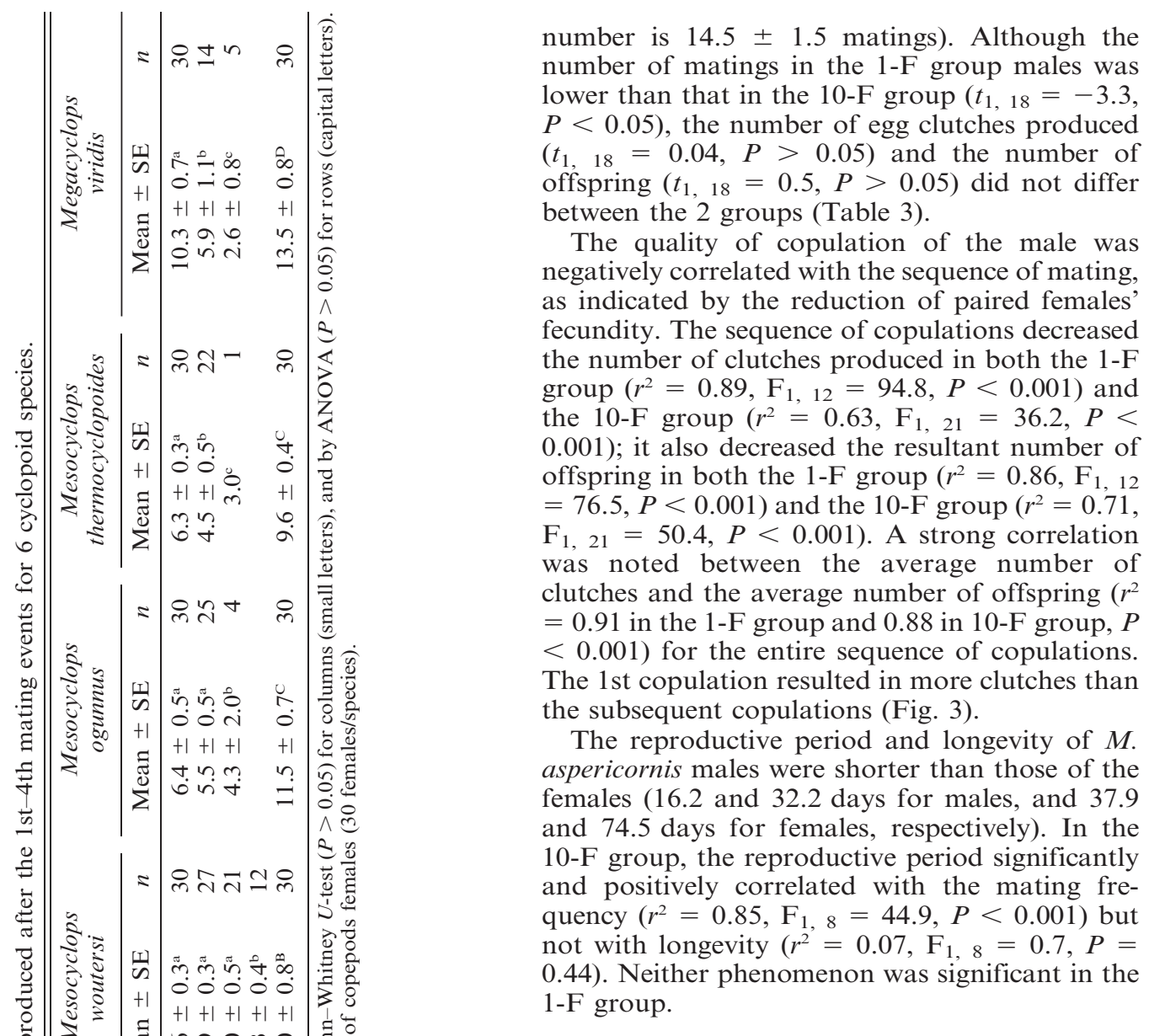

\section{Fecundity after 30 days of storage}

After 30 days of storage under moist conditions, the inseminated $M$. aspericornis females reproduced without another mating. The number of clutches in these females was lower than that of the control group that was maintained in the culture solution $\left(t_{1,58}=-3.9\right.$ in $15^{\circ} \mathrm{C}, t_{1,58}=$ -4.1 in $25^{\circ} \mathrm{C}$, respectively, $P<0.001$ ) (Table 4). The storage period of 30 days did not affect the survivorship of the offspring of these females (average number of offspring per brood) as compared with those of the control group. The longevity of the females was not affected when maintained at $25^{\circ} \mathrm{C}\left(t_{1}, 58=0.3, P>0.05\right)$ but was negatively effected when stored at $15^{\circ} \mathrm{C}\left(t_{1}, 58\right.$ $=-10.0, P<0.001)$ (Table 4).

\section{DISCUSSION}

Previously, selection of an appropriate cyclopoid candidate for operational control programs was usually based on cyclopoid size and daily killing rate, with some consideration of temperature tolerance (Brown et al. 1991, Jennings et al. 1995, Nam et al. 2000). Our data demonstrate 
Table 2. Clutch size, interclutch period, and the longevity of females for 6 copepod species.

\begin{tabular}{|c|c|c|c|c|c|c|}
\hline \multirow[b]{2}{*}{ Copepod species } & \multicolumn{2}{|c|}{ Clutch size } & \multicolumn{2}{|c|}{ Interclutch period } & \multicolumn{2}{|c|}{ Longevity (days) } \\
\hline & Mean $\pm \mathrm{SE}$ & $n$ & Mean $\pm \mathrm{SE}$ & $n$ & Mean $\pm \mathrm{SE}$ & $n$ \\
\hline Mesocyclops aspericornis & $117.0 \pm 1.8^{\mathrm{a} 1}$ & 100 & $1.3 \pm 0.03^{\mathrm{a}}$ & 30 & $74.5 \pm 0.5^{\mathrm{a}}$ & 18 \\
\hline Mesocyclops ogunnus & $70.0 \pm 0.8^{\mathrm{b}}$ & 100 & $1.5 \pm 0.04^{\mathrm{b}}$ & 19 & $43.1 \pm 0.4^{\mathrm{b}}$ & 30 \\
\hline Mesocyclops pehpeiensis & $90.6 \pm 1.0^{c}$ & 100 & $1.5 \pm 0.04^{\mathrm{b}}$ & 27 & $50.9 \pm 0.5^{\mathrm{b}}$ & 19 \\
\hline Mesocyclops & & & & & & \\
\hline thermocyclopoides & $88.0 \pm 1.1^{\mathrm{c}}$ & 100 & $1.4 \pm 0.04^{\mathrm{a}}$ & 30 & $31.2 \pm 0.5^{\mathrm{c}}$ & 23 \\
\hline Mesocyclops woutersi & $81.6 \pm 1.3^{\mathrm{c}}$ & 100 & $1.4 \pm 0.03^{\mathrm{a}}$ & 23 & $56.5 \pm 0.5^{\mathrm{d}}$ & 27 \\
\hline Megacyclops viridis & $51.7 \pm 0.7^{\mathrm{d}}$ & 100 & $2.0 \pm 0.04^{\mathrm{c}}$ & 30 & $65.0 \pm 0.5^{\mathrm{a}}$ & 30 \\
\hline
\end{tabular}

${ }^{1}$ Values in the same column with the same letter do not differ significantly, as determined by ANOVA $(P>0.05)$.

that some species such as $M$. aspericornis can be long-lived (up to 74.5 days with a prolonged reproductive life of up to 43 days) and highly fecund (18 clutches each with an average of 117 offspring). This clearly needs to be considered as a benefit if faced with choosing between this species and $M$. thermocyclopoides, for example, which has a shorter longevity (31.2 days) and reproduced for an average of 36.5 days to produce an average of 9.6 clutches of 88 offspring. Our data, therefore, provide additional information on 5 Mesocyclops species commonly found throughout Asia (Kay et al. 2001) and elsewhere that have utility for mosquito control.

\section{Mating behavior}

In nature, if only a single mating of an adult female is needed to realize her maximum reproductive potential, low mating rates may not be a large barrier for reproduction (Buskey, 1998). Maier (1994) reported that both $C$. vicinus and $M$. minutus avoid remating after their initial mating, although densities and thus encounter rates between the sexes was high. This behavior appears to be an adaptation to avoid the competition of sperm from multiple matings when the sperm still remains in the seminal receptacle of the female. However, our data show that although the cyclopoid copepod females can store the sperm and produce several clutches of viable offspring from a single mating, when the supply of stored sperm was exhausted and no further egg clutches were produced, the copepod females of all 6 species tested showed that they require and engage in subsequent mating. Be- cause the males are smaller than the females (Dussart and Defaye 1995), remating behavior was more frequent in the 5 Mesocyclops species tested than in $M$. viridis, and this may be due to sex size dimorphism in the latter. With $M$. minutus, Maier (1994) reported that its extraordinarily low sex size dimorphism related to its remating frequency.

In natural habitats, where copepods are a part of complex ecological communities, mating behavior might be a key factor in structuring the size and species composition of zooplankton communities, and frequent mating and/or a long mating period would probably increase the risk of predation (Maier et al. 2000). Thus, the short mating process (a few minutes) observed in Mesocyclops species should reduce the risk of predation, but multiple mating compounds this risk since conjoined pairs are not as agile. Males also depart immediately after spermatophore transfer to escape cannibalistic copepod females, a phenomenon previously observed in European Mesocyclops leuckarti (Claus) (Maier 1994).

\section{Influence of mating frequency on maternal fecundity}

Remating has been rarely studied in cyclopoid copepods, and mating frequency has been assumed to be an unimportant factor (Maier et al. 1994, Hopp et al. 1997, Maier et al. 2000). However, the present study demonstrated that 3 or 4 matings were ordinary for Mesocyclops. Depending upon the species and quantity of sperm, a Mesocyclops female typically produces 3 to 8 clutches, and then subsequent remating occurs to produce additional egg clutches.

Table 3. Reproductive traits of male Mesocyclops aspericornis paired daily with a single female or a group of 10 females; $n=$ number of males.

\begin{tabular}{lcccc}
\hline \hline & $n$ & $\begin{array}{c}\text { Number of } \\
\text { copulations per male } \\
\text { (mean } \pm \text { SE) }\end{array}$ & $\begin{array}{c}\text { Number of } \\
\text { clutches per male } \\
\text { (mean } \pm \mathrm{SE})\end{array}$ & $\begin{array}{c}\text { Number of } \\
\text { offspring per male } \\
(\text { mean } \pm \mathrm{SE})\end{array}$ \\
\hline $1-\mathrm{F}$ group & 10 & $8.5 \pm 1.1^{\mathrm{a} 1}$ & $63.7 \pm 8.9^{\mathrm{a}}$ & $1,385 \pm 183.4^{\mathrm{a}}$ \\
$10-\mathrm{F}$ group & 10 & $14.5 \pm 1.5^{\mathrm{b}}$ & $63.20 \pm 6.9^{\mathrm{a}}$ & $1,267 \pm 142.5^{\mathrm{a}}$ \\
\hline
\end{tabular}

\footnotetext{
${ }^{1}$ Values in the same column with the same letter do not differ significantly, as determined by the $t$-test $(P>0.05)$.
} 

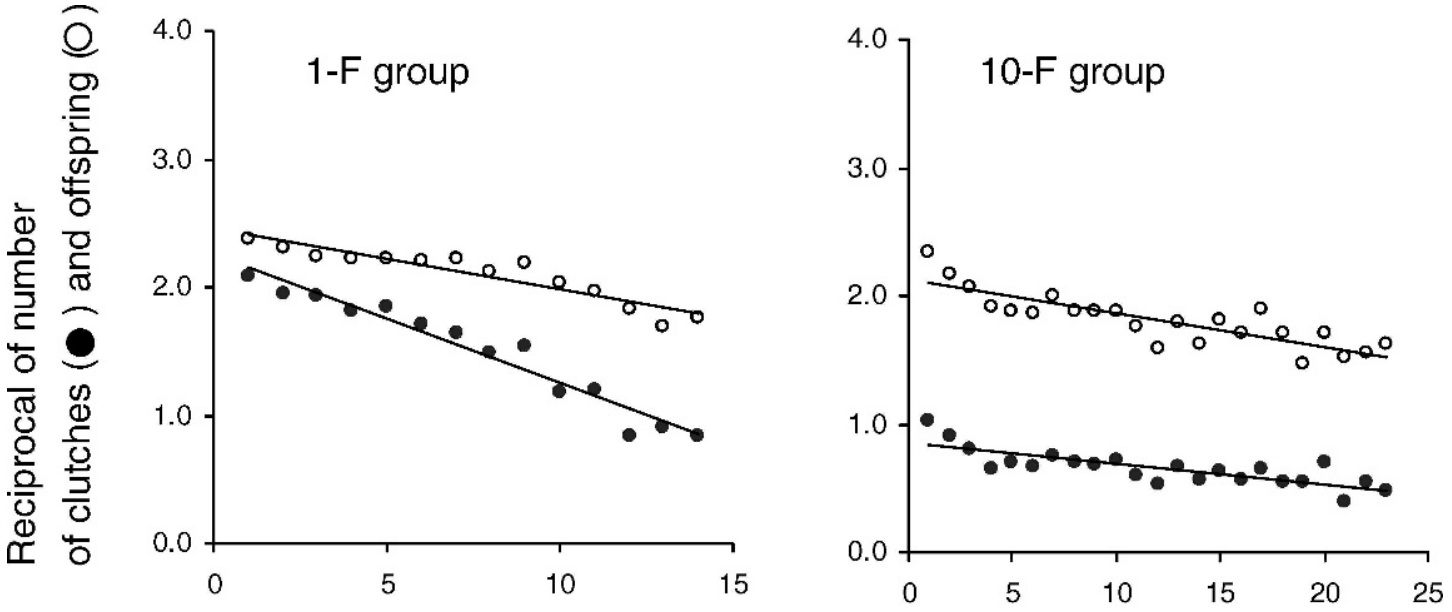

\section{Sequence of copulated females}

Fig. 3. Reciprocal of the number of egg clutches and offspring produced by males having daily single (1-F group) and multiple copulations (10-F group) as a function of the copulation sequence of $M$. aspericornis males. The data of number of clutches and offspring were normalized using a $\log _{10}+1$ transformation.

The cost of reproduction in terms of reduced longevity was absent in all 6 copepod species tested, and the positive correlations among the fitness traits observed in this study may be due to the adequate food supply and an absence of density-dependent competition under the experimental conditions. Reproduction of mated $\mathrm{Me}$ socyclops edax (Forbes) females reduced adult survivorship as compared with unmated females under temperature-stressed (1-h exposure at $36^{\circ} \mathrm{C}, 38.5^{\circ} \mathrm{C}$, and $41^{\circ} \mathrm{C}$ ) and unstressed conditions (1-h exposure at $30^{\circ} \mathrm{C}$ and $34^{\circ} \mathrm{C}$ ) (Brian 1983).

Species-specific fecundity is also an important indicator in choosing candidate species for mass production and application in the field for vector control. The high reproductive capacity of $M$. aspericornis, $M$. pehpeiensis, and M. woutersi confirmed in this study coincide with their successful use for dengue vector control in Vietnam (Nam et al. 2000, Kay et al. 2002, Kay and Nam 2005, Nam et al. 2005).

\section{Influence of mating frequency on paternal fecundity}

The role of males in reproduction has been poorly studied. This is probably because cyclopoid copepod females store sperm to fertilize several egg clutches. Mesocyclops aspericornis males copulate with as many females as possible (average of 14.5 females) when many females are present in the habitat. With 1 female group, the average number of matings was 7.5 , but in both cases, the insemination capacity was gradually lost. This phenomenon has been noted in other biological systems. For example, Hausermann and Nijhout (1975) observed that an average $A e$. aegypti male could fully inseminate 4 to 5 females and transmit small amounts of sperm to an additional 2 to 4 females.

Although the initial copulation of males resulted in a higher maternal fecundity as compared with the subsequent copulations, the quantity of sperm was insufficient to realize the potential lifetime fecundity of the females. Thus,

Table 4. Average number of clutches, length of reproductive period, longevity, and average number of offspring produced by Mesocyclops aspericornis-inseminated females after preservation for 30 days in moist filter paper at $15^{\circ} \mathrm{C}$ or $25^{\circ} \mathrm{C}$. The control referred to 30 new inseminated M. aspericornis females.

\begin{tabular}{|c|c|c|c|c|c|c|c|c|}
\hline \multirow[b]{2}{*}{ Groups } & \multicolumn{2}{|c|}{$\begin{array}{l}\text { Number of clutches } \\
\text { (per female) }\end{array}$} & \multicolumn{2}{|c|}{$\begin{array}{l}\text { Reproductive } \\
\text { period (days) }\end{array}$} & \multicolumn{2}{|c|}{ Longevity (days) } & \multicolumn{2}{|c|}{$\begin{array}{l}\text { Number of offspring } \\
\text { (per brood) }\end{array}$} \\
\hline & Mean $\pm \mathrm{SE}$ & $n$ & Mean $\pm \mathrm{SE}$ & $n$ & Mean $\pm \mathrm{SE}$ & $n$ & Mean $\pm \mathrm{SE}$ & $n$ \\
\hline Storage at $15^{\circ} \mathrm{C}$ & $4.8 \pm 0.2^{\mathrm{a} 1}$ & 30 & $10.3 \pm 0.5^{\mathrm{a}}$ & 30 & $26.2 \pm 2.6^{\mathrm{a}}$ & 30 & $24.9 \pm 0.9^{\mathrm{a}}$ & 145 \\
\hline Storage at $25^{\circ} \mathrm{C}$ & $4.4 \pm 0.4^{\mathrm{a}}$ & 30 & $9.0 \pm 0.6^{\mathrm{a}}$ & 30 & $69.6 \pm 3.2^{\mathrm{b}}$ & 30 & $25.2 \pm 1.1^{\mathrm{a}}$ & 148 \\
\hline Control & $6.9 \pm 0.5^{\mathrm{b}}$ & 30 & $11.0 \pm 1.1^{\mathrm{a}}$ & 30 & $68.5 \pm 3.3^{b}$ & 30 & $23.3 \pm 0.6^{\mathrm{a}}$ & 178 \\
\hline
\end{tabular}

${ }^{1}$ Values in the same column with the same letter do not differ significantly, as determined by the $t$-test $(P>0.05)$. 
multiple copulations appear to be an ecological adaptive strategy for copepod males to contribute toward population growth, because copepod males have a lower sex proportion (Dussart and Defaye 1995), a shorter reproductive period and longevity compared to females, and suffer a high risk of cannibalism by copepod females when food availability is low in natural habitats.

\section{Fecundity after 30 days of storage}

Cyclopoid copepods can enter dormancy at late juvenile stages, and dormant cyclopoid copepods may survive years of desiccation (Wyngaard et al. 1991, Maria et al. 2001). Our study showed that inseminated females can reproduce after 30 days of storage under moist conditions. Viable sperm enables copepods to delay their reproduction and survive under unfavorable conditions, but ensures their survival when conditions become favorable. Thus, maintaining inseminated females in wet rubber foam at room temperature for 30 days is a promising method for their transfer and delivery to the communities for dengue control (Kay et al. 2002, Nam et al. 2005). Our data suggest that such transportation may also be possible using layers of moist filter paper, which could save postage costs when sent by mail.

\section{ACKNOWLEDGMENTS}

We would like to thank Brian H. Kay, Grace Wyngaard, Gerald G. Marten, Vu Sinh Nam, Nguyen Thi Yen, Maria Holynska, Tessa Knox, and Toshihiko Sunahara for their helpful suggestions and editing of the manuscript.

\section{REFERENCES CITED}

Brian PF, Wyngaard AG, Allan JD. 1983. The cost of reproduction in a freshwater copepod. Oecologia 56:166-168.

Brown MD, Kay BH, Hendrikz JK. 1991. Evaluation of Australian Mesocyclops (Copepoda: Cyclopidae) for mosquito control. J Med Entomol 28:618-623.

Buskey EJ. 1998. Components of mating behavior in planktonic copepods. J Mar Syst 15:13-21.

Dieng H, Boots M, Tuno N, Tsuda Y, Takagi M. 2003. Life history effects of prey choice by copepods: implications for biocontrol of vector mosquitoes. J Am Mosq Control Assoc 19:67-73.

Dussart BH, Defaye D. 1995. Copepoda. Introduction to the Copepoda. Amsterdam, the Netherlands: SPD Academic.

Hansen AM, Santer B. 1995. The influence of food resources on the development, survival, reproduction of the two cyclopoid copepods: Cyclops vicinus and Mesocyclops leuckarti. J Plankton Res 17:631-646.

Hausermann W, Nijhout HF. 1975. Permanent loss of male fecundity following sperm depletion in Aedes aegypti (L.). J Med Entomol 11:707-722.
Holynska M, Reid JW, Ueda H. 2003. Genus Mesocyclops Sars, 1914. In: Veda H and Reid JW, eds. Guide to the identification of the microinvertebrates of the continental waters of the world, 20. Copepoda: Cyclopoida. Genera Mesocyclops and Thermocyclops. Leiden, the Netherlands: Backhuys Publishers.

Hopp U, Maier G, Bleher R. 1997. Reproduction and adult longevity of five species of planktonic cyclopoid copepods reared on different diets: a comparative study. Freshw Biol 38:289-300.

Jennings CD, Phommasack B, Sourignadeth S, Kay BH. 1995. Aedes aegypti control in the Lao People's Democratic Republic, with reference to copepods. Am J Trop Med Hyg 53:324-330.

Kay BH, Nam VS. 2005. New strategy against Aedes aegypti in Vietnam. Lancet 365:613-619.

Kay BH, Nam VS, Tien TV, Yen NT, Phong TV, Diep VT, Ninh TU, Bektas A, Aaskov JG. 2002. Control of Aedes vectors of dengue in three provinces of Vietnam by use of Mesocyclops (Copepoda) and community-based methods validated by entomologic, clinical, and serological surveillance. Am J Trop Med Hyg 66:40-47.

Kay BH, Nam VS, Yen NT, Tien TV, Holynska M. 2001. Successful dengue vector control in Vietnam: a model for regional consideration. Arbovirus Res Aust 8:187-193.

Lardeux FJR. 1992. Biological control of culicidae with the copepod Mesocyclops aspericornis and larvivorous fish (Poeciliidae) in a village in French Polynesia. Med Vet Entomol 6:9-15.

Maier G. 1995. Mating frequency and interspecific mating in some freshwater cyclopoid copepods. Oecologia 101:245-250.

Maier G, Berger I, Burghard W, Nassal B. 2000. Is mating of copepods associated with increased risk of predation? J Plankton Res 22:1977-1987.

Maria CB, William FL, Reid JW, Sue AP. 2001. Diapause in copepods (Crustacea) from ephemeral habitats with different hydroperiods in Everglades National Park (Florida, USA) Hydrobiologia 453: 295-308.

Marten GG, Astaiza R, Suarez MF, Monje C, Reid JW. 1989. Natural control of larval Anopheles albimanus (Diptera: Culicidae) by the predator Mesocyclops (Copepoda: Cyclopoida). J Med Entomol 26:624627.

Marten GG, Borjas G, Cush M, Fernandez E, Reid JW. 1994. Control of larval Aedes aegypti (Diptera: Culicidae) by cyclopoid copepods in peridomestic breeding containers. J Med Entomol 31:36-44.

Nam VS, Yen NT, Holynska M, Reid JW, Kay BH. 2000. National progress in dengue vector control in Vietnam: survey for Mesocyclops (Copepoda), Micronecta (Corixidae), and fish as biological control agents. Am J Trop Med Hyg 62:5-10.

Nam VS, Yen NT, Phong TV, Ninh TU, Mai LQ, Lo LV, Nghia LT, Bektas A, Briscombe A, Aaskov JG, Ryan PA, Kay BH. 2005. Elimination of dengue by community programs using Mesocyclops (copepoda) against Aedes aegypti in central Vietnam. Am J Trop Med Hyg 72:67-73.

Phong TV, Nam VS, Yen NT, Bin NT. 1996. Mesocyclops (Copepoda) in the area of no dengue cases reported, Quoc Oai, Ha Tay \& Gia Luong, Ha Bac, 1993-1995. J Practical Med Vietnam Minist Health 12:231-234. 
Suarez MF, Marten GG, Clark GG. 1992. A simple method for cultivating freshwater copepods used in biological control of Aedes aegypti. J am Mosq Control Assoc 8:409-412.

Torres-Estrada JL, Cruz-Lopez L, Arredondo-Jimenez JI. 2001. Selective oviposition by Aedes aegypti (Diptera: Culicidae) in response to Mesocyclops longisetus (Copepoda: Cyclopoidea) under laboratory and field conditions. J Med Entomol 38:188-192.

Williamson CE, Butler NM. 1987. Temperature, food and mate limitation of copepod reproductive rates: separating the effects of multiple hypotheses. J Plankton Res 9:821-836.

Wyngaard GA. 1986. Genetic differentiation of life history traits in populations of Mesocyclops edax (Crustacea: Copepoda). Biol Bull 170:279-295.

Wyngaard GA, Taylor BE, Mahoney DM. 1991. Emergence and dynamics of cyclopoid copepods in an unpredictable environment. Freshw Biol 25:219-232.

Zhen TM, Jennings CD. 1994. Laboratory studies of desiccation resistance in Mesocyclops (Copepoda: Cyclopoida). J Am Mosq Control Assoc 10:443-446. 